\title{
Genomic and Non-genomic Action of Neurosteroids in the Peripheral Nervous System
}

\author{
Alessandra Colciago, Veronica Bonalume, Valentina Melfi and Valerio Magnaghi* \\ Department of Pharmacological and Biomolecular Sciences, Università degli Studi di Milano, Milan, Italy
}

Since the former evidence of biologic actions of neurosteroids in the central nervous system, also the peripheral nervous system (PNS) was reported as a structure affected by these substances. Indeed, neurosteroids are synthesized and active in the PNS, exerting many important actions on the different cell types of this system. PNS is a target for neurosteroids, in their native form or as metabolites. In particular, old and recent evidence indicates that the progesterone metabolite allopregnanolone possesses important functions in the PNS, thus contributing to its physiologic processes. In this review, we will survey the more recent findings on the genomic and non-genomic actions of neurosteroids in nerves, ganglia, and cells forming the PNS, focusing on the

OPEN ACCESS

Edited by:

Hubert Vaudry,

Université de Rouen, France

Reviewed by:

Michael Schumacher,

Institut National de la Santé et de la Recherche Médicale (INSERM),

France

Shogo Haraguchi,

Showa University, Japan

*Correspondence:

Valerio Magnagh

valerio.magnaghi@unimi.it

Specialty section:

This article was submitted to Neuroendocrine Science,

a section of the journal

Frontiers in Neuroscience

Received: 25 March 2020

Accepted: 07 July 2020

Published: 29 July 2020

Citation:

Colciago A, Bonalume V, Melfi V and Magnaghi V (2020) Genomic and Non-genomic Action of Neurosteroids in the Peripheral

Nervous System.

Front. Neurosci. 14:796.

doi: 10.3389/fnins.2020.00796 mechanisms regulating the peripheral neuron-glial crosstalk. Then, we will refer to the physiopathological significance of the neurosteroid signaling disturbances in the PNS, in to identify new molecular targets for promising pharmacotherapeutic approaches.

Keywords: neuroactive steroid, allopregnanolone, GABA, myelin, Schwann cell, dorsal root ganglia

\section{INTRODUCTION}

The importance of endogenous neurosteroids for the control of the peripheral nervous system (PNS) become increasingly relevant in the last decades. Since the 1980 last century, when Baulieu and colleagues (Baulieu, 1997) introduced the term "neurosteroids" to indicate steroids that were synthesized de novo in the brain, also the PNS has

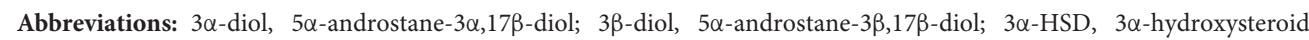
dehydrogenase; $3 \beta$-HSD, $3 \beta$-hydroxysteroid dehydrogenase; $5 \alpha-\mathrm{R}, 5 \alpha$-reductase; $5 \mathrm{HT}_{3}$, 5 -hydroxytryptamine type 3; ALLO, allopregnanolone; AR, androgen receptor; CREB, cAMP response element-binding protein; DHEA, dehydroepiandrosterone; DHP, dihydroprogesterone; DHT, dihydrotestosterone; DRG, dorsal root ganglia; E2, 17 $\beta$-estradiol; EAAC1, excitatory amino acid transporter 1; EGR1/Krox-24 early growth response (EGR1/Krox-24); EGR2/Krox-20 early growth response 2 (EGR2/Krox-20); Egr3, early growth response 3; ER, estrogen receptor; ERK1/2, extracellular signal-regulated protein kinase 1 and 2; FAK, focal adhesion kinase; GABA, $\gamma$-aminobutirric acid; GABA-A, GABA type A receptor; GABAB, GABA type B receptor; GAD67, glutamic acid decarboxylase of $67 \mathrm{kDa}$; GFAP, glial fibrillary acidic protein; GPCR, G protein-coupled receptor; GPR30, GPCR ER-1 or GPER1; GR, glucocorticoid receptor; LXR, liver X receptor; MAG, myelin associated glycoprotein; mAR, membrane androgen receptor; MEP, motor exit point; mER, membrane estrogen receptor; $\mathrm{mGR}$, membrane glucocorticoids receptor; $\mathrm{mPR}$, membrane progesterone receptor; $\mathrm{MR}$, mineralocorticoid receptor; NCV, nerve conduction velocity; NMDA, N-Methyl-D-aspartate; Olig1, oligodendrocyte transcription factor 1; P0, glycoprotein P0; P450C17, 17 $\alpha$-hydroxylase/17,20-lyase; P450scc, P450 side-chain cleavage enzyme; p75-NTR, neurotrophin receptor p75; PAQR, progestin and adipoQ receptor family; PGRMC-1, PR membrane component-1; PHTPP, 2-Phenyl3-(4-hydroxyphenyl)-5,7-bis(trifluoromethyl)-pyrazolo[1,5-a]pyrimidine; PK-A, protein kinase A; PK-C, protein kinase C; PMP22, peripheral myelin protein 22; PNS, peripheral nervous system; PR, progesterone receptor, PREG, pregnenolone; PROG, progesterone; SC, Schwann cells; Shh, sonic hedgehog; Src, tyrosine protein kinase Src; SRC1, steroid nuclear receptor coactivator; Sox-10, SRY-box10; StAR, steroidogenic acute regulatory protein; STZ, streptozotocin; T, testosterone; THDOC, tetrahydrodesoxycorticosterone; THP, tetrahydroprogesterone; TSPO, translocator protein. 
been referred as an important target of their action. In the PNS, the neuroactive steroids (comprising the aforementioned neurosteroids as well as the hormonal steroids) are synthesized and/or metabolized in active forms and exert important physiopathologic functions.

The neurosteroidogenic machinery includes a set of enzymes (Figure 1), starting from P450 side-chain cleavage (P450scc), which convert cholesterol into pregnenolone (PREG) in mitochondria, moving to the $3 \beta$-hydroxysteroid-dehydrogenase (3 $\beta$-HSD), that converts PREG into progesterone (PROG) or the 17 $\alpha$-hydroxylase/17,20-lyase (P450C17), converting PREG into dehydroepiandrosterone (DHEA). These steroids may be then metabolized into androgens, androstenediol, androstenedione and testosterone (T). Furthermore, by the action of the enzyme P450 aromatase the androgens androstenedione and $\mathrm{T}$ are converted into the estrogens estrone and $17 \beta$-estradiol (E2), respectively.

Most of these enzymes, as well as their metabolic products PROG, PREG, T, DHEA, and E2, have been found in PNS (Caruso et al., 2008). In particular, the glial Schwann cells (SC) of the PNS possess the enzymatic machinery required to produce the neurosteroids: P450scc, 3 $\beta$-HSD, etc., (Celotti et al., 1992; Melcangi et al., 2001; Schumacher et al., 2001). The activity of some steroidogenic enzymes in SC is neuronal dependent, such as the $3 \beta-H S D$, that raised in the presence of neurons (Chan et al., 2000; Robert et al., 2001). Dorsal root ganglia (DRG) express the P450scc and $3 \beta$-HSD but not other steroidogenic enzymes, indicating that other autocrine or paracrine mechanisms might influence the steroidogenesis in the soma of primary sensory neurons (Schaeffer et al., 2010). Additionally, the enzymatic complexes formed by the $5 \alpha$-reductase $(5 \alpha-\mathrm{R})$ and the $3 \alpha$-hydroxysteroid-dehydrogenase ( $3 \alpha-$ HSD) was found in the PNS (Figure 1), primarily in SC (Melcangi et al., 1990; Celotti et al., 1992; Melcangi et al., 1992, 1999b). This enzymatic complex converts steroids possessing the delta(4)-3-keto configuration into their more active $5 \alpha-3 \alpha$-reduced metabolites, the so-called neuroactive steroids (Celotti et al., 1992). Thereby, the PROG is converted into dihydroprogesterone (DHP) and then into $5 \alpha$-pregnan$3 \alpha$-ol-20-one, also named tetrahydroprogesterone (THP) or allopregnanolone (ALLO); similarly, the steroid $\mathrm{T}$ is converted into dihydrotestosterone (DHT) then into $5 \alpha$-androstane$3 \alpha, 17 \beta$-diol ( $3 \alpha$-diol). The $5 \alpha$-reduced intermediate metabolite DHP and DHT can be further converted, by the enzyme $3 \beta-H S D$, into $5 \alpha$-pregnan-3 $\beta$-ol-20-one (also named isopregnanolone) or $5 \alpha$-androstane- $3 \beta, 17 \beta$-diol ( $3 \beta$-diol), respectively (Giatti et al., 2015; Figure 1).

The PNS showed also the presence of other important factors supporting de novo local synthesis of neuroactive steroids. For instance, those factors regulating the translocation of cholesterol into the mitochondria, likely the steroidogenic acute regulatory protein (StAR) and the translocator protein of $18 \mathrm{kDa}$ (TSPO), as well as the liver X receptor (LXR), were found to be present and active in peripheral nerves. TSPO was formerly considered as a crucial protein for steroid biosynthesis ( $\mathrm{Li}$ and Papadopoulos, 1998). More recent and debated observations, however, argued the significance of TSPO in steroidogenesis and evidenced its involvement in pathological conditions, like inflammation, apoptosis and neurological diseases (e.g., Alzheimer's disease or multiple sclerosis); indeed, TSPO seems to be expressed only in response to insults and pathological states (Bonsack and Sukumari-Ramesh, 2018). In the PNS, the activation of TSPO with the specific ligand Ro5-4864 improved the levels of neuroactive steroids and exerted neuroprotective effects in the peripheral nerves of streptozotocin (STZ)-induced diabetic rats (Giatti et al., 2009). LXR is a ligand activated transcription factor belonging to the nuclear receptor superfamily. It is important for cholesterol biosynthesis, serving as a sensor that prevents the excessive intracellular accumulation of cholesterol (Jakobsson et al., 2012). In the PNS, its activation by specific ligands induces neuroactive steroid synthesis in the sciatic nerve of STZ-induced diabetic rats, thus ameliorating diabetes-induced neuropathy (Cermenati et al., 2010).

Interestingly, the synthesis and the levels of neuroactive steroids proved sexually dimorphic, in physiologic states (Melcangi et al., 2016), as well as in peripheral neurodegenerative conditions, such as the diabetic neuropathy (Pesaresi et al., 2010). For instance, in the sciatic nerve of STZ-rats the levels of PREG, T, DHT, and $3 \alpha$-diol decreased in males, whereas the levels of PROG, THP and isopregnanolone drop down only in female (Pesaresi et al., 2010). In the same rat model of diabetic neuropathy, the gonadectomy ameliorates the nerve alterations in females but not in males (Pesaresi et al., 2011a).

In this review, we will survey the recent findings of the classical and non-classical, genomic and non-genomic action of neuroactive steroids in peripheral nerves, ganglia and cells forming the PNS, thereby focusing on the mechanisms regulating the peripheral neuron-glial crosstalk.

\section{MECHANISMS OF ACTION OF NEUROACTIVE STEROIDS}

In the PNS, the neuroactive steroids exert several biologic functions, modulating the mitogenic activity, cell proliferation, myelination process, nerve repair, and axonal conduction.

The neuroactive steroid actions occur through either "classical" or "non-classical" receptors, which localized both in the neuronal and in the glial compartment (i.e., $\mathrm{SC}$ ) of the PNS. The classical action is generally genomic and consists of the binding to intracellular receptors in the target cells, followed by the regulation of gene transcription (Slater et al., 1994). Conversely, the non-classic action is more rapid and involves the modulation of membrane receptors, such as neurotransmitter and neurotrophin receptors, ion channels or the newest membrane steroid receptors (Brann et al., 1995; Barabas et al., 2018). Commonly, among the neurotransmitter receptors affected by neuroactive steroids, there are the $\gamma$-aminobutyric acid (GABA) and the N-Methyl-D-aspartate (NMDA) receptors (Lambert et al., 1996; Rupprecht et al., 2001; Monnet and Maurice, 2006; Sedlacek et al., 2008). Moreover, the family of steroid membrane receptors includes specific receptors for estrogens, androgens, glucocorticoids and progestogens (Levin, 2011). Whether these receptors are the classical 


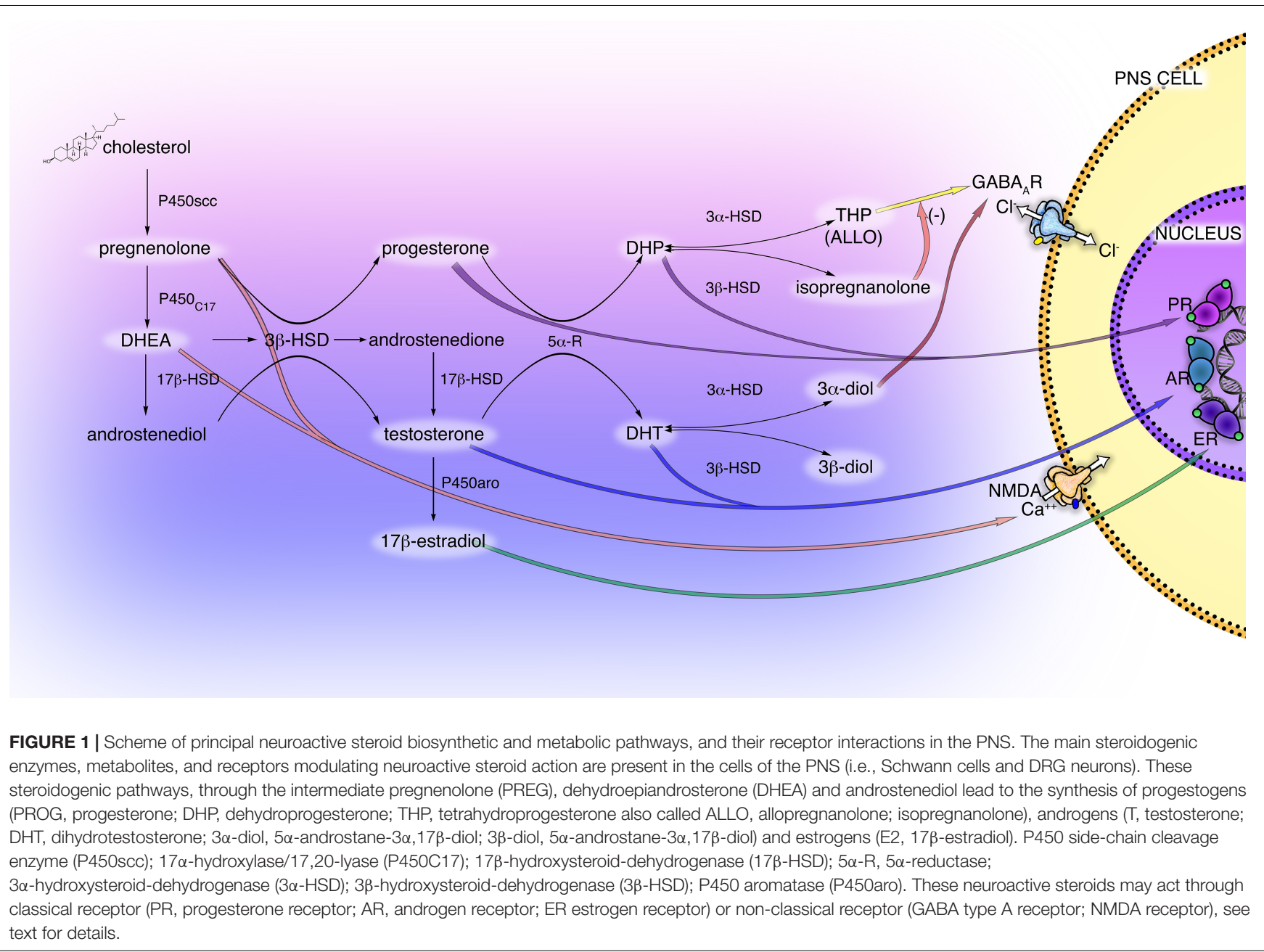

nuclear receptor, which localizes on the cell membrane, or distinct receptors characterized by different proteins is still a matter of debate.

Interestingly, the capability of neuroactive steroids to interact with classical rather than non-classical receptors is ancillary to their conversion into active compounds. For instance (Figure 1), the progestogens PROG and DHP mainly exert classical activity through the genomic PROG receptor (PR), while their metabolite ALLO fulfills a non-classical activity via the GABA type A (GABA-A) receptor. Indeed, ALLO is one of the most re-known and important GABA-A receptor modulators (Lambert et al., 2009; Faroni and Magnaghi, 2011), while the progestogen metabolite isopregnanolone has proved to antagonize the effect of ALLO at GABA-A receptor (Wang et al., 2002). Similarly, androgen metabolites exert classical and non-classical actions. For instance, (Figure 1) 3 $\alpha$-diol activates the GABA-A receptor, whereas $3 \beta$-diol is an agonist of the estrogen receptor (ER) beta (ER $\beta$ ) (Lambert et al., 2003; Handa et al., 2008).

Evidence on the involvement of all these receptors in the different physiopathologic states affecting the PNS has been fully reported.

\section{GENOMIC ACTIONS OF NEUROACTIVE STEROIDS IN PNS}

Classical intracellular steroid receptors, such as PR, ER, androgen receptor (AR), glucocorticoid receptor (GR), and mineralocorticoid receptor (MR) were found in peripheral nerves (Magnaghi et al., 1999, 2001; Jordan et al., 2002; Shaqura et al., 2016) as well as in SC (Neuberger et al., 1994; Jung-Testas et al., 1996; Groyer et al., 2006; Faroni and Magnaghi, 2011; Shaqura et al., 2016) and DRG (Luo et al., 2008; Dong et al., 2012; Shaqura et al., 2016; Figure 1). Generally, these classic receptors bind, respectively, the progestogens PROG and DHP, the estrogens E2 and estrone, the androgens DHEA, T and DHT, the gluco/mineralocorticoids corticosterone, dehydrocorticosterone, and deoxycorticosterone (Slater et al., 1994; Prough et al., 2016).

In the PNS, E2 promoted the proliferation and differentiation of SC, in vitro and in vivo, thus fostering the myelination process (Chen et al., 2016; Gu et al., 2018). By the way, some of these effects were inhibited by the antagonist of the genomic ER type $\alpha(E R \alpha)$ and type $\beta$ (ER $\beta$ ) receptors, ICI182780 and 2-phenyl-3-(4-hydroxyphenyl)-5,7-bis(trifluoromethyl)pyrazolo[1,5-a]pyrimidine (PHTPP), respectively, highlighting 
a classical genomic mechanism. Nevertheless, the specific block of the intracellular signaling cascade of the extracellular signal-regulated protein kinase $1 / 2$ (ERK1/2) or AKT (commonly downstream the activation of the membrane receptor) evidenced that also these pathways may occur, and suggested that the mechanisms are complicated, likely involving both genomic and non-genomic actions (Gu et al., 2018). Besides, also PROG was able to promote SC proliferation, and its effects appeared sex-specific (JungTestas et al., 1993). E2 was effective in males, while PROG promotes SC proliferation only in females. These actions implied genomic mechanisms since they were blocked by specific ER $\alpha$ and PR antagonists, ICI128780 and zk112994, respectively, (Fex Svenningsen and Kanje, 1999).

In the PNS, the effect of neuroactive steroids been extensively studied on the myelination and re-myelination processes has been extensively studied. The glucocorticoid corticosterone stimulated the expression of the two most important proteins of the peripheral myelin (Desarnaud et al., 2000): the glycoprotein $\mathrm{P} 0$ (P0) and the peripheral myelin protein of $22 \mathrm{kDa}$ (PMP22). However, progestogens were proved as the more compelling steroids able to regulate the PNS myelination. PROG, DHP, and ALLO stimulated the expression of P0 and PMP22 in the sciatic nerve of young and old male rats (Melcangi et al., 1998, 1999a, 2000b; Faroni and Magnaghi, 2011). In in vivo models, PROG, DHP and ALLO proved able to reduce the age-associated myelin abnormalities in the sciatic nerve of elderly rats (Azcoitia et al., 2003) and stimulated the re-myelination of injured nerves, in a model of nerve cryolesion or transection (Koenig et al., 1995; Melcangi et al., 2000a). Furthermore, in a model of guided facial nerve regeneration, PROG increased the SC proliferation, myelination as well as the number of nerve fibers (ChavezDelgado et al., 2005). The effects of PROG and DHP on P0 and PMP22 levels occurred also in SC cultures (Desarnaud et al., 1998; Melcangi et al., 1998, 1999a; Magnaghi et al., 2001), indicating a direct classical genomic effect of progestogens on these cells. In accordance, we proposed that the complicated and long-term effects of PROG, DHP and ALLO (after its retro-conversion into DHP, within PNS cells; see Figure 1) in modulating the expression of protein $\mathrm{P} 0$ are linked to the interaction with the PR expressed in SC (Magnaghi et al., 2001). The specific PR antagonist mifepristone (RU38486), indeed, blocked the effects of PROG, DHP and ALLO on the P0 levels (Melcangi et al., 2003), corroborating the genomic mechanism. Nevertheless, the rapid effect of ALLO on PMP22 levels seemed due to an interaction with the GABA-A receptor expressed in SC (see the chapter below).

The classical genomic effect on P0 was sustained by the presence of putative PROG responsive elements on the P0 gene (Magnaghi et al., 1999) and by the involvement of the steroid nuclear receptor coactivator SRC1 in the regulation of P0 expression (Cavarretta et al., 2004). Interestingly, the genomic action exerted by progestogens on the PNS myelin proteins, that is P0, PMP22 and myelin associated glycoprotein (MAG), was sex-specific; in fact male rats resulted more responsive to the genomic effects of PROG and DHP (Magnaghi et al., 2006b). It was highlighted that PROG coordinates also the initiation of the PNS myelination, because it increases the expression of some basic transcription factors priming the SC myelination, such as early growth response 2 EGR2 (EGR2/Krox-20), early growth response (EGR1/Krox-24), early growth response 3 (Egr3), SRY-box10 (Sox10) and Fos B (Guennoun et al., 2001; Mercier et al., 2001; Magnaghi et al., 2007). At least in the case of Krox-20, the presence of putative PROG responsive elements in the gene promoter support a PR-mediated genomic effect (Magnaghi et al., 2007).

Other findings suggested that the glycoprotein $\mathrm{P} 0$ is also under the control of classical AR. Gonadectomy of adult male rats induced a decrease in myelin protein $\mathrm{P} 0$, whereas DHT enhanced the P0 levels in sciatic nerve of normal animals (Magnaghi et al., 1999). This effect attested the capacity of androgens to participate in the control of peripheral myelination, however, since the SC do not express AR (Magnaghi et al., 1999), the effect was supposed to be indirectly mediated via the neuronal compartment. The androgens efficacy may be ascribed to the crosstalk between SC and the axon, hypothesizing the transfer of vesicles likely containing the receptors (Grossfeld et al., 1988; Lopez-Verrilli and Court, 2012), or the involvement of motoneurons which express the AR (Jordan et al., 2002). The finding that genomic effects of neuroactive steroids on SC are indirectly mediated by the neuronal compartment is supported by the observation that the PR antagonist mifepristone induced an axonal impairment during the development, determining a significant reduction of axon diameter (Melcangi et al., 2003). In accordance, the PROG enhancement of myelin formation was shown in an in vitro co-culture model of SC-DRG neurons, corroborating the requirement of the neuronal compartment for the progestogen action (Chan et al., 2000).

Neuroactive steroids, mainly PROG and DHP, also exert neuroprotective and pro-regenerative effects in case of neurodegenerative pathologies of the PNS, such as nerve traumatic injuries (i.e., cryolesion, transection or crush) or diabetic neuropathy (Koenig et al., 1995; Melcangi et al., 2000a; Chavez-Delgado et al., 2005; Leonelli et al., 2007; Roglio et al., 2008). For instance, PROG and DHP, likely through genomic mechanisms involving the $\mathrm{PR}$, are able to counteract the decrease of P0 and PMP22 expression induced in the STZ model of diabetic neuropathy (Leonelli et al., 2007). Both neuroactive steroids decreased the number of altered fibers (i.e., presenting myelin infoldings) in the sciatic nerve of STZ neuropathic rats (Veiga et al., 2006), still corroborating the neuroprotective role of PR. In parallel, also the androgen DHT proved able to increase the P0 mRNA levels in the sciatic nerve of STZ neuropathic rats, likely via AR-mediated mechanisms (Roglio et al., 2007). In the same model of STZ-induced neuropathy, DHP and DHT improved another hallmark of diabetic neuropathy, promoting the changes in $\mathrm{Na}^{+}-\mathrm{K}^{+}$ATPase activity (Leonelli et al., 2007; Roglio et al., 2007). In diabetic rats, also the treatment with DHEA exerted neuroprotective effects, mostly in females rather than in male animals (Pesaresi et al., 2011b). DHEA was effective following rat sciatic nerve transection, whereas it reduced the extent of denervation atrophy stimulating the earlier onset of axonal regeneration (Ayhan et al., 2003). Following traumatic nerve crush injury, DHEA and E2 promote the fast recovery of 
gait along with an enhancement of myelinated fibers (Gudemez et al., 2002; Islamov et al., 2002). Moreover, also T was capable to accelerate the functional recovery following rat sciatic nerve crush (Kujawa et al., 1993; Brown et al., 1999).

Evidence of GR-dependent induction of gene transcription was found in adult DRG neurite, which grew in response to stress or glucocorticoid treatment. This phenomenon exacerbates the effect of acute systemic stress on neuronal plasticity and PNS regeneration (Lerch et al., 2017). Importantly, a putative role of GR in regulating peripheral nociception has been proposed. This hypothesis was corroborated by the GR localization, which was found predominantly in peripheral nociceptive unmyelinated C-fiber and A $\delta$ lightly myelinated fibers (Shaqura et al., 2016).

\section{NON-GENOMIC ACTION OF NEUROACTIVE STEROIDS IN PNS: ROLE OF MEMBRANE STEROID RECEPTORS}

The steroid membrane receptors mediate the rapid (second to minutes) non-classical, non-genomic action of neuroactive steroids, occurring at the cell surface of neurons and glial cells. To date, it consists of specific receptors for estrogens (membrane $\mathrm{ER}, \mathrm{mER}$ ), androgens (membrane AR, mAR) glucocorticoids (membrane GR, mGR) and progestogens (membrane PR, mPR). These receptors mostly belong to the $\mathrm{G}$ protein-coupled receptor (GPCR) family and activate a plethora of intracellular signaling cascade (Levin, 2011). Recent studies investigated the presence of some membrane receptors in the PNS, focusing primarily on the subfamilies $\mathrm{mER}$ and $\mathrm{mPR}$.

The GPR30, named GPCR ER-1 (GPER1), is a non-nuclear ER located on the cell membrane, which binds E2 with high affinity and potency, thus mediating non-genomic events (Thomas et al., 2005). DRG, autonomic pelvic ganglia and sensory trigeminal ganglia express GPR30, which modulation by the specific G1 agonist induced a membrane depolarization (Dun et al., 2009). In the PNS, however, some rapid estrogenic effect seemed to be due to the non-genomic action of classic ER $\alpha$, likely translocated to the cell membrane. For instance, mouse DRG neurons express membrane associated $\mathrm{ER} \alpha$, producing a rapid attenuation of ATP-induced $\mathrm{Ca}^{++}$signaling, likely a mechanism involved in gender-specific pain perception (Chaban and Micevych, 2005). Another study underlined the cytoprotective potential of E2 on the transplanted SC in a model of spinal cord injury (Siriphorn et al., 2010). Protection was not inhibited by classical ER antagonist ICI 182780, suggesting that non-genomic mechanisms involving mER may occur (Siriphorn et al., 2010).

In the last decade, five subtypes of mPRs $(\mathrm{mPR} \alpha-\varepsilon)$ were classified. These receptors are GPCRs, belong to the progestin and adipoQ receptor family (PAQR) and mediate rapid neuroprotective actions of progestogens (i.e., PROG and ALLO) in the nervous system (Thomas and Pang, 2012). The PR membrane component-1 (PGRMC-1; formerly named $25 \mathrm{Dx})$ is another protein complexing with the plasminogen activator inhibitor 1 RNA binding protein and able to bind PROG (Peluso et al., 2008; Cooke et al., 2013). PGRMC1 was implicated in the neuroprotective effects of PROG following traumatic brain injury (Meffre et al., 2013) and spinal cord injury (De Nicola et al., 2009). Although it was found in S42 SC line (Castelnovo et al., 2019), the possible function in PNS was not further investigated. Very recently, some mPRs (primarily $\mathrm{mPR} \alpha$ and $\mathrm{mPR} \beta$ ) were found in PNS and in SC in vitro (Figure 2), whereby they promote cell migration, proliferation and differentiation (Castelnovo et al., 2019, 2020). Indeed, in SC, mPR activation with the specific ligand $\mathrm{O} 2$ induced rapid downregulation of myelinating (i.e., Sox10 and Krox20) and non-myelinating [i.e., glial fibrillary acidic protein (GFAP) and neurotrophin receptor p75 (p75-NTR)] markers of SC. Contemporarily, other specific markers of repairing SC [i.e., oligodendrocyte transcription factor 1 (Olig1) and sonic hedgehog (Shh)] resulted up- and/or down-regulated following mPR activation (Castelnovo et al., 2020). These effects were mediated by an intracellular activation of phosphorylated AKT (Figure 2). Overall, these observations proved a direct control of $\mathrm{SC}$ by $\mathrm{mPR}$, playing a promising role in the promotion of nerve re-growth (Castelnovo et al., 2019, 2020).

Recent work shed light on a peripheral glial population named "motor exit point" (MEP) glia, possessing some typical features of peripheral SC, that might be relevant in spinal cord regeneration (Fontenas and Kucenas, 2018). Theoretically, it could be speculated that $\mathrm{mPR}$ exerts a direct neuroprotective effect within the spinal cord through the MPR stimulation of MEP glial cells, although this hypothesis deserves further proof.

Apparently less investigated, also the mGR subfamily was studied in the PNS. Evidence of a putative non-genomic pathway including GR binding sites has been found in membrane fractions of DRG neurons, suggesting a potential rapid, GPCR-linked, non-genomic mechanism for $\mathrm{mGR}$ in mediating peripheral pain (Shaqura et al., 2016).

\section{NON-GENOMIC ACTION OF NEUROACTIVE STEROIDS IN PNS: INVOLVEMENT OF GABA AND OTHER RECEPTORS}

Besides the steroid membrane receptors, the non-classical action of neuroactive steroids comprises the modulation of other membrane receptors, for instance, the neurotransmitter receptors GABA-A, GABA type B (GABA-B), NMDA, 5hydroxytryptamine type $3\left(5-\mathrm{HT}_{3}\right)$ and $\sigma 1$ receptors (Lambert et al., 1996, 2009; Rupprecht et al., 2001; Monnet and Maurice, 2006; Sedlacek et al., 2008).

GABA-A receptor is a member of the ligand-gated ion channel family, permeable to a $\mathrm{Cl}^{-}$flux and composed of five subunits from a repertoire of nineteen isoforms (i.e., $\alpha 1-6, \beta 1-3, \gamma 1-3$, $\delta, \varepsilon, \pi, \theta, \rho 1-3)$ (Whiting et al., 1995, 1997; Lambert et al., 2003). GABA-A receptor is allosterically activated by neuroactive steroids, mainly ALLO but also $3 \alpha$-diol, $3 \beta$-diol and the corticosteroid $5 \alpha-3 \alpha$ metabolite tetrahydrodesoxycorticosterone (THDOC) (Reddy and Rogawski, 2002). In this regard, it is the most studied non-genomic mechanism of neuroactive steroids in the nervous system as well as in the PNS (Park-Chung et al., 


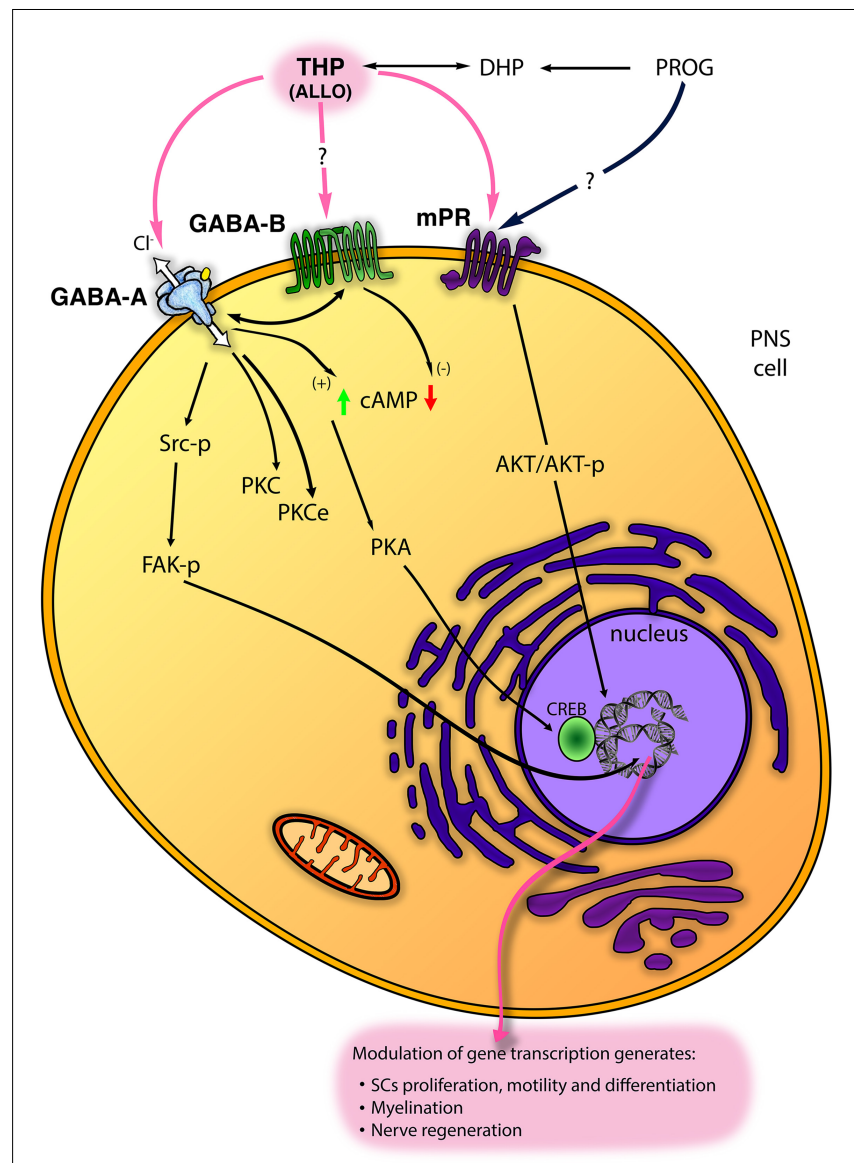

FIGURE 2 | Scheme of main non-classical mechanisms of progestogens (PROG, progesterone and THP, tetrahydroprogesterone also called ALLO, allopregnanolone) in the PNS. ALLO may interact with GABA type A receptor (GABA-A), although its modulation of GABA type B receptor (GABA-B) receptor has been proposed. In SC, ALLO and likely PROG interact with the membrane PROG receptor (mPR). Some intracellular signalings downstream these receptors (including Src/FAK kinases; protein kinase C, PKC, and PKC $\epsilon$; cyclic AMP, cAMP, and protein kinase A, PKA, etc.) are reported (see text for details).

1999; Belelli and Lambert, 2005). GABA-A receptor is classified in different subtypes based on its subunit composition. The receptor formed by one $\alpha(\alpha 2-5)$ plus $\beta 3$ and $\gamma 2$ subunits gives consistent potentiation to the ALLO-mediated GABA-activated currents (Hosie et al., 2009), while $\delta$-containing subtype was classically described at extrasynaptic sites whereby it is highly sensitive to the $5 \alpha$-3 $\alpha$-reduced metabolites (Mihalek et al., 1999; Belelli et al., 2002). In the PNS, GABA-A receptor is widely distributed in nerves, neurons, and glial cells. SC express the $\alpha 2$ and $3, \beta 1$, 2, 3 and $\gamma 2$ subunits (Melcangi et al., 1999a; Magnaghi et al., 2006a), as well as the $\alpha 4$ and $\delta$ subunits, more characteristic of the extrasynaptic receptor (Faroni et al., 2019). In addition, we found most of these subunits in the mouse DRG neuronal cultures, with predominant expression of the synaptic subunits $\alpha 1, \alpha 2, \beta 1, \beta 3$, $\gamma 2$ (Faroni et al., 2019). In general, in the PNS, the role of ALLO through GABA-A receptor has been widely characterized in the glial compartment, showing enhancement of SC proliferation, motility, differentiation and myelination (Figure 2; see also the following chapter). ALLO non-classical non-genomic effects were mimicked also by PROG and DHP, but only in prolonged (e.g., $24 \mathrm{~h}$ ) treatment condition, when progestogens can be converted into their $5 \alpha-3 \alpha$ metabolite ALLO, then exerting its action via GABA-A receptor modulation (Figure 2). Recently, in DRG sensory neuron, GABA-A receptor has been characterized for its relevance in controlling peripheral pain (Chen et al., 2014; Zhang et al., 2015; Du et al., 2017), albeit ALLO's allosteric modulation of GABA-A receptor in pain was not yet fully investigated.

Interestingly, some evidence suggests that neuroactive steroids require a different route of access to the transmembrane-domain binding sites within GABA-A receptor (Shu et al., 2004; Akk et al., 2005; Hosie et al., 2006; Chisari et al., 2009). Neuroactive steroids may be entrapped in the intracellular compartment, then re-supply the cell membrane with ligands able to modulate the GABA-A receptor at later times; by this way, the kinetic of neuroactive steroid action at GABA-A receptor may be modulated by neuroactive steroids themselves (Akk et al., 2005). In accordance, the regulation of the lipid components of the peripheral myelin may be considered as a kind of nonclassical non-genomic action of neuroactive steroids in the PNS. Although this uncommon mechanism was exerted by DHP, usually acting through the classic genomic PR action, it lies in the middle ground of a genomic/non-genomic mechanism. However, in a model of diabetic neuropathy, DHP proved able to promote fatty acid desaturation and to reduce the morphological alteration of nerves, reaffirming its neuroprotective role in PNS (Mitro et al., 2014).

In principle, the possibility of ALLO to interact with the metabotropic GABA-B receptor should not be completely excluded (Figure 2). To date, although a direct interaction of ALLO with GABA-B receptor was not clearly stated, several pieces of evidence highlighted a cross-regulation between GABAA and GABA-B receptors in PNS (Magnaghi, 2007; Faroni et al., 2019). For instance, ALLO exerted a GABA-A mediated biphasic control of different GABA-B receptor subunits (Magnaghi et al., 2006a; Magnaghi, 2007). The metabotropic GABA-B receptor is a dimeric complex, a member of the GPCR superfamily (Bowery and Enna, 2000). In the PNS, GABA-B receptor subunits $1 \mathrm{a}, 1 \mathrm{~b}$ and 2 were found in SC, sciatic nerve, satellite cells and DRG neurons (Magnaghi et al., 2004; Magnaghi, 2007; Faroni et al., 2014), where the functional receptor was proved to be negatively coupled to the adenylate cyclase system (Figure 2; Magnaghi et al., 2004). Its activation decreased SC proliferation and the expression of some important myelin proteins, like P0, PMP22, MAG and connexin 32 (Magnaghi et al., 2004). In a neuropathic model of partial sciatic ligation, a 7-day administration of specific GABA-B ligands (i.e., baclofen and the antagonist CGP56433) strongly improved the biochemical, morphological and behavioral outcomes of sciatic nerve (Magnaghi et al., 2014). Furthermore, studies in transgenic mice with a conditional deletion of GABA-B1 receptor in PNS demonstrated that some important GABA-A subunits, expressed in SC and DRG neurons, were cross-regulated by GABA-B receptor (Faroni et al., 2019).

Beside the GABA-A receptor, other neurotransmitter receptors, such as NMDA receptor, are affected by neuroactive 
steroids (Figure 1). Indeed, it was shown that PREG, DHEA and DHEA sulfate activate allosterically NMDA receptor (Figure 1), while PREG sulfate acts as the negative modulator ( $\mathrm{Wu}$ et al., 1991; Baulieu, 1997; Park-Chung et al., 1999). NMDA is an ionotropic glutamate receptor also distributed in the PNS, where it localizes in peripheral axons and SC (Evans et al., 1991, 1992; Carlton et al., 1998; Christensen et al., 2016; Campana et al., 2017). The PNS also has specific glutamate transporters and it synthesizes glutamate, which was found in sensory and motor neurons (Chen et al., 2017). Moreover, sensory cranial ganglia synthesize glutamate (Malet and Brumovsky, 2015), while the SC possess the enzymatic machinery able to uptake and synthesize glutamate, like the excitatory amino acid transporter 1 (EAAC1) and glutamine synthetase (Miller et al., 2002; Perego et al., 2012). The $\sigma 1$ receptor is an intracellular protein that localizes in membranes of the endoplasmic reticulum, plasmalemma, nucleus, and mitochondria (Alonso et al., 2000) and it is able to enhance NMDA activity (Pabba and Sibille, 2015). Activation of this receptor rises intracellular $\mathrm{Ca}^{++}$influx via NMDA (Hayashi et al., 2000), thus confirming the capability of $\sigma 1$ to modulate NMDA receptor. Accordingly, it was shown that DHEA sulfate acts as $\sigma 1$ agonist, inducing a clear $\sigma 1$-like potentiation of NMDA response, while PREG sulfate exerted opposite effects; also PROG is an endogenous antagonist of $\sigma 1$ receptor (Maurice et al., 1999). To date, evidence of neuroactive steroid actions through NMDA or $\sigma 1$ receptor, specifically in the PNS, has not been yet provided.

\section{ALLO ACTIVATION OF GABA-A RECEPTOR IN PNS: INTRACELLULAR SIGNALING}

ALLO is the most re-known neuroactive steroid able to regulate the PNS, controlling glial proliferation, differentiation and myelination processes (Figure 2). ALLO non-genomic effects on GABA-A receptors usually occurred at nanomolar concentration, engaging an allosteric interaction that entails the presence of the endogenous ligand GABA. Instead, at high concentration (micromolar range) ALLO directly gates GABA-A receptor (Callachan et al., 1987), although it was shown that neuroactive steroids might directly gate GABA-A receptor even at $100 \mathrm{nM}$, likely attaining a relatively low kinetic (Shu et al., 2004).

In any case, the presence of endogenous GABA is a requisite for ALLO action. Following the former observation in the early 1980's proving GABAergic fibers in PNS (Brown and Marsh, 1978; Morris et al., 1983; Olsen et al., 1984), it was unequivocally demonstrated the presence of GABA and its synthetic machinery (glutamic acid decarboxylase of $67 \mathrm{kDa}, \mathrm{GAD67}$ ) in SC (Magnaghi et al., 2010). An autocrine loop has been proposed, through which nanomolar concentration of ALLO was able to increase the GAD67 levels in SC, thus providing GABA as the endogenous ligand for the GABA-A receptor (Magnaghi et al., 2010). Therefore, the local GABA synthesis in peripheral nerves supports the allosteric action of ALLO in SC and neighboring compartments. In accordance, it was shown that SC possesses EAAC1, the active uptake system able to provide glutamate as a precursor for GABA synthesis (Perego et al., 2011,
2012). In SC, EAAC1 expression and activity were still controlled by ALLO, through a GABA-A mediated and protein kinase $\mathrm{C}$ (PKC) mechanisms (Figure 2) ALLO promoted the transport of EAAC1 from the intracellular stores into the SC membrane (in actin-rich cell tips), modifying their morphology (Perego et al., 2012).

ALLO was shown to increase SC proliferation (Perego et al., 2012; Melfi et al., 2017) and this action was GABAA mediated because it was mimicked by the specific ligand muscimol and blocked by the specific antagonist bicuculline (Perego et al., 2012). It was highlighted that ALLO's control of SC proliferation was dependent on EAAC1 transport and activity at SC plasma membrane (Perego et al., 2012), once again confirming that GABA synthesis was necessary for ALLO effects. ALLO also stimulated morphologic changes and motility of SC, then promoting myelination (Melfi et al., 2017), which are fundamental processes for the development, maturation, and regeneration of PNS. Remarkably, ALLO participated in the control of peripheral myelin proteins (e.g., P0, MAG), being particularly active in enhancing the levels of PMP22, mRNA and protein (Melcangi et al., 1999a,b; Magnaghi et al., 2001). The specificity of this action was confirmed, respectively, by the capability of muscimol to replicate and of bicuculline to abolish the ALLO's effects on PMP22 (Magnaghi et al., 2001, 2006a). This confirmed the hypothesis that in SC protein PMP22 is controlled by GABA-A receptors. However, the capability to stimulate PMP22 expression was observed also with $3 \alpha$-diol (Magnaghi et al., 2001), likely via the same allosteric GABA-A receptor modulation (Frye et al., 1996; Figure 1).

As expected, the intracellular mechanisms downstream the ALLO modulation of GABA-A receptors imply changes in intracellular $\mathrm{Cl}^{-}$flux (Figure 2). Conversely, at least in PNS, most of ALLO effects reflected as transcriptional changes. In the last decades, some studies were addressed to clear this point. For instance, in the developing rat cortex, GABAA receptor activation leads to an increase of $\mathrm{Ca}^{++}$influx through L-type voltage-gated $\mathrm{Ca}^{++}$channels. This leads to the phosphorylation and activation of the cAMP response elementbinding protein (CREB) transcription factor, in turn regulating protein expression, for instance of the brain derived neurotrophic factor (Mantelas et al., 2003). Unfortunately, these mechanisms were not shown in the PNS, whereas the concomitant activation of ion channels (e.g., $\mathrm{Ca}^{++}$channels), following neuroactive steroid binding to GABA-A receptor, is still questionable. Although the involvement of $\mathrm{Ca}^{++}$channel is not clear, ALLO was proved able to modulate the protein kinase A (PK-A), through enhanced cAMP levels and CREB phosphorylation (Magnaghi et al., 2010), or the PKC pathway (Perego et al., 2012; Figure 2). These intracellular signalings were supposed to be downstream the allosteric action of ALLO at GABA-A receptor. Recently, another intracellular ALLO's pathway has been found. ALLO effects on SC proliferation, motility and myelination, indeed, imply tyrosine protein kinase Src (Src) and focal adhesion kinase (FAK) activation (Melfi et al., 2017), although other signaling pathways should not be excluded (Figure 2). ALLO effects on Src were mimicked by muscimol, counteracted by bicuculline and by the specific Src inhibitor PP2, suggesting that in SC ALLO activation of GABA-A induces an intracellular 
phosphorylation cascade, leading to actin rearrangements of the cytoskeleton, enhancement of SC motility and myelination (Melfi et al., 2017; Figure 2).

One strategy that neuroactive steroids use to control GABAA receptor function is to phosphorylate/de-phosphorylate its subunits by the recruitment of protein kinases or phosphatases (Belelli and Lambert, 2005). Phosphorylation of GABA-A can produce different effects, ranging from enhancement to inhibition, depending on the subunit targeted and on the location of sites being phosphorylated (Moss and Smart, 1996). In parallel, PKC phosphorylation of GABA-A receptor may influence the sensitivity to neuroactive steroids (Brussaard and Koksma, 2003; Vergnano et al., 2007). Accordingly, PKC- $\varepsilon$ is considered as a novel isoform of $\mathrm{PKC}$, regulating the sensitivity to neuroactive steroids. Indeed, animals lacking PKC- $\varepsilon$ showed hypersensitivity to behavioral effects induced with allosteric GABA-A receptor modulation (Hodge et al., 2002). PKC- $\varepsilon$ was found in SC and DRG neurons in culture (Puia et al., 2015). Interestingly, PKC- $\varepsilon$ was upregulated in DRG neurons exposed to the culture medium from ALLO-treated SC, suggesting that these cells release one or more factors able to regulate PKC- $\varepsilon$ in DRG neurons (Puia et al., 2015). Since PKC- $\varepsilon$ is relevant in modulating some pain pathways, we speculated that these mechanisms identified novel putative circuits involved in the control of pain processes at PNS and spinal cord levels (Puia et al., 2015).

In the PNS, ALLO hired importance also during neurodegenerative conditions, likely implying the regulation of other nervous cells or structures (i.e., DRG neurons). In a model of STZ-induced diabetic neuropathy, ALLO and $3 \alpha$-diol enhanced nerve conduction velocity (NCV) and intraepidermal nerve density, decreasing sensitivity to thermal pain (Leonelli et al., 2007; Roglio et al., 2007). Although the mechanism behind these effects was not elucidated, the involvement of non-genomic mechanisms through GABA-A receptor was hypothesized. In support of the non-genomic action of ALLO in neuropathic pain (Patte-Mensah et al., 2014), it should be highlighted that ALLO may regulate other channels and/or signaling pathways involved in neuropathic pain, such as T-type $\mathrm{Ca}^{++}$channels, voltage-gated $\mathrm{Na}^{+}$channels, purinergic receptor P2X3 and bradykinin signaling (Cho and Chaban, 2012; Ayoola et al., 2014).

\section{REFERENCES}

Akk, G., Shu, H. J., Wang, C., Steinbach, J. H., Zorumski, C. F., Covey, D. F., et al. (2005). Neurosteroid access to the GABAA receptor. J. Neurosci. 25, 11605-11613. doi: 10.1523/jneurosci.4173-05.2005

Alonso, G., Phan, V., Guillemain, I., Saunier, M., Legrand, A., Anoal, M., et al. (2000). Immunocytochemical localization of the sigma(1) receptor in the adult rat central nervous system. Neuroscience 97, 155-170. doi: 10.1016/s03064522(00)00014-2

Ayhan, S., Markal, N., Siemionow, K., Araneo, B., and Siemionow, M. (2003). Effect of subepineurial dehydroepiandrosterone treatment on healing of transected nerves repaired with the epineurial sleeve technique. Microsurgery 23, 49-55. doi: $10.1002 / \mathrm{micr} .10088$

Ayoola, C., Hwang, S. M., Hong, S. J., Rose, K. E., Boyd, C., Bozic, N., et al. (2014). Inhibition of CaV3.2 T-type calcium channels in peripheral sensory neurons

\section{CONCLUSION}

In this review, we sum up most of the latest evidence on the effects of neuroactive steroids, either classical or non-classical, genomic or non-genomic, in the PNS. Neuroactive steroids exhibit important functions in the development, myelination, neuroprotection and nerve repair of the PNS. In particular, ALLO revealed the most well studied and incisive neuroactive steroid in regulating the biologic and physiologic functions of the PNS. Here we reported several steps forward in the identification of its mechanism of action. Some ALLO's effects may be ascribed to GABA-A (or likely GABA-B) activation, PKA, PKC or PKC- $\varepsilon$ modulation, as well as to the Src/FAK kinases involvement. Besides, $\mathrm{mPR}$ or electrophysiological changes in ion channels, likely $\mathrm{Cl}^{-}$flux, have been recently proposed to occur also in the PNS.

Interestingly, the neuroregenerative effects of ALLO via GABA-A receptor might be promising for the treatment of the peripheral neurodegenerative pathologies, particularly for traumatic injuries requiring the surgical application of bioengineered conduits. Indeed, in vitro testing of 2D silk fibroin scaffold, functionalized for controllable in situ delivery of ALLO, showed great potential for nerve repair (Gennari et al., 2018). Therefore, the administration of neuroactive steroids might represent a novel and promising strategy to prevent or treat different types of peripheral neuropathies and the associated neuropathic pain.

\section{AUTHOR CONTRIBUTIONS}

AC wrote and revised the whole manuscript. VB prepared the figures and revised the manuscript. VMe searched the bibliography and proofread the manuscript. VMa planned, wrote and revised the whole manuscript. All authors contributed to the article and approved the submitted version.

\section{ACKNOWLEDGMENTS}

The authors are grateful to Astrid William, for her helpful discussion and reviewing of the manuscript.

contributes to analgesic properties of epipregnanolone. Psychopharmacology 231, 3503-3515. doi: 10.1007/s00213-014-3588-0

Azcoitia, I., Leonelli, E., Magnaghi, V., Veiga, S., Garcia-Segura, L. M., and Melcangi, R. C. (2003). Progesterone and its derivatives dihydroprogesterone and tetrahydroprogesterone reduce myelin fiber morphological abnormalities and myelin fiber loss in the sciatic nerve of aged rats. Neurobiol. Aging 24, 853-860. doi: 10.1016/s0197-4580(02)00234-8

Barabas, K., Godo, S., Lengyel, F., Ernszt, D., Pal, J., and Abraham, I. M. (2018). Rapid non-classical effects of steroids on the membrane receptor dynamics and downstream signaling in neurons. Horm. Behav. 104, 183-191. doi: 10.1016/j. yhbeh.2018.05.008

Baulieu, E. E. (1997). Neurosteroids: of the nervous system, by the nervous system, for the nervous system. Recent Prog. Horm. Res. 52, 1-32.

Belelli, D., Casula, A., Ling, A., and Lambert, J. J. (2002). The influence of subunit composition on the interaction of neurosteroids with GABA(A) 
receptors. Neuropharmacology 43, 651-661. doi: 10.1016/s0028-3908(02) 00172-7

Belelli, D., and Lambert, J. J. (2005). Neurosteroids: endogenous regulators of the GABA(A) receptor. Nat. Rev. Neurosci. 6, 565-575. doi: 10.1038/nrn1703

Bonsack, F., and Sukumari-Ramesh, S. (2018). TSPO: an evolutionarily conserved protein with elusive functions. Int. J. Mol. Sci. 19:1694. doi: 10.3390/ ijms19061694

Bowery, N. G., and Enna, S. J. (2000). gamma-aminobutyric acid(B) receptors: first of the functional metabotropic heterodimers. J. Pharmacol. Exp. Ther. 292, 2-7.

Brann, D. W., Hendry, L. B., and Mahesh, V. B. (1995). Emerging diversities in the mechanism of action of steroid hormones. J. Steroid Biochem. Mol. Biol. 52, 113-133. doi: 10.1016/0960-0760(94)00160-n

Brown, D. A., and Marsh, S. (1978). Axonal GABA-receptors in mammalian peripheral nerve trunks. Brain Res. 156, 187-191. doi: 10.1016/0006-8993(78) 90098-7

Brown, T. J., Khan, T., and Jones, K. J. (1999). Androgen induced acceleration of functional recovery after rat sciatic nerve injury. Restor. Neurol. Neurosci. 15, 289-295.

Brussaard, A. B., and Koksma, J. J. (2003). Conditional regulation of neurosteroid sensitivity of GABAA receptors. Ann. N. Y. Acad. Sci. 1007, 29-36.

Callachan, H., Cottrell, G. A., Hather, N. Y., Lambert, J. J., Nooney, J. M., and Peters, J. A. (1987). Modulation of the GABAA receptor by progesterone metabolites. Proc. R. Soc. Lond. B. Biol. Sci. 231, 359-369. doi: 10.1098/rspb. 1987.0049

Campana, W. M., Mantuano, E., Azmoon, P., Henry, K., Banki, M. A., Kim, J. H., et al. (2017). Ionotropic glutamate receptors activate cell signaling in response to glutamate in Schwann cells. FASEB J. 31, 1744-1755. doi: 10.1096/ fj.201601121r

Carlton, S. M., Chung, K., Ding, Z., and Coggeshall, R. E. (1998). Glutamate receptors on postganglionic sympathetic axons. Neuroscience 83, 601-605. doi: 10.1016/s0306-4522(97)00406-5

Caruso, D., Scurati, S., Maschi, O., De Angelis, L., Roglio, I., Giatti, S., et al. (2008). Evaluation of neuroactive steroid levels by liquid chromatographytandem mass spectrometry in central and peripheral nervous system: effect of diabetes. Neurochem. Int. 52, 560-568. doi: 10.1016/j.neuint.2007.06.004

Castelnovo, L. F., Caffino, L., Bonalume, V., Fumagalli, F., Thomas, P., and Magnaghi, V. (2020). Membrane progesterone receptors (mPRs/PAQRs) differently regulate migration, proliferation, and differentiation in rat schwann cells. J. Mol. Neurosci. 70, 433-448. doi: 10.1007/s12031-019-01433-6

Castelnovo, L. F., Magnaghi, V., and Thomas, P. (2019). Expression of membrane progesterone receptors (mPRs) in rat peripheral glial cell membranes and their potential role in the modulation of cell migration and protein expression. Steroids 142, 6-13. doi: 10.1016/j.steroids.2017.09.009

Cavarretta, I. T. R., Martini, L., Motta, M., Smith, C. L., and Melcangi, R. C. (2004). SRC-1 is involved in the control of the gene expression of myelin protein Po. J. Mol. Neurosci. 24, 217-226. doi: 10.1385/jmn:24:2:217

Celotti, F., Melcangi, R. C., and Martini, L. (1992). The 5 alpha-reductase in the brain: molecular aspects and relation to brain function. Front. Neuroendocrinol. $13,163-215$.

Cermenati, G., Giatti, S., Cavaletti, G., Bianchi, R., Maschi, O., Pesaresi, M., et al. (2010). Activation of the liver $\mathrm{X}$ receptor increases neuroactive steroid levels and protects from diabetes-induced peripheral neuropathy. J. Neurosci. 30, 11896-11901. doi: 10.1523/jneurosci.1898-10.2010

Chaban, V. V., and Micevych, P. E. (2005). Estrogen receptor-alpha mediates estradiol attenuation of ATP-induced $\mathrm{Ca} 2+$ signaling in mouse dorsal root ganglion neurons. J. Neurosci. Res. 81, 31-37. doi: 10.1002/jnr.20524

Chan, J. R., Rodriguez-Waitkus, P. M., Ng, B. K., Liang, P., and Glaser, M. (2000). Progesterone synthesized by Schwann cells during myelin formation regulates neuronal gene expression. Mol. Biol. Cell 11, 2283-2295. doi: 10.1091/mbc.11. 7.2283

Chavez-Delgado, M. E., Gomez-Pinedo, U., Feria-Velasco, A., Huerta-Viera, M., Castaneda, S. C., Toral, F. A., et al. (2005). Ultrastructural analysis of guided nerve regeneration using progesterone- and pregnenolone-loaded chitosan prostheses. J. Biomed. Mater. Res. B Appl. Biomater. 74, 589-600. doi: 10.1002/ jbm.b.30243

Chen, J. T., Guo, D., Campanelli, D., Frattini, F., Mayer, F., Zhou, L., et al. (2014). Presynaptic GABAergic inhibition regulated by BDNF contributes to neuropathic pain induction. Nat. Commun. 5:5331.
Chen, T. J., Frohlich, N., Kula, B., Barzan, R., and Kukley, M. (2017). Glutamate activates AMPA receptor conductance in the developing schwann cells of the mammalian peripheral nerves. J. Neurosci. 37, 11818-11834. doi: 10.1523/ jneurosci.1168-17.2017

Chen, Y., Guo, W., Xu, L., Li, W., Cheng, M., Hu, Y., et al. (2016). 17betaestradiol promotes schwann cell proliferation and differentiation, accelerating early remyelination in a mouse peripheral nerve injury model. Biomed. Res. Int. 2016:7891202.

Chisari, M., Eisenman, L. N., Krishnan, K., Bandyopadhyaya, A. K., Wang, C., and Taylor, A. (2009). The influence of neuroactive steroid lipophilicity on GABAA receptor modulation: evidence for a low-affinity interaction. J. Neurophysiol. 102, 1254-1264. doi: 10.1152/jn.00346.2009

Cho, T., and Chaban, V. V. (2012). Interaction between P2X3 and oestrogen receptor (ER)alpha/ERbeta in ATP-mediated calcium signalling in mice sensory neurones. J. Neuroendocrinol. 24, 789-797. doi: 10.1111/j.1365-2826.2011. 02272.x

Christensen, P. C., Welch, N. C., Brideau, C., and Stys, P. K. (2016). Functional ionotropic glutamate receptors on peripheral axons and myelin. Muscle Nerve 54, 451-459. doi: $10.1002 /$ mus. 25078

Cooke, P. S., Nanjappa, M. K., Yang, Z., and Wang, K. K. (2013). Therapeutic effects of progesterone and its metabolites in traumatic brain injury may involve nonclassical signaling mechanisms. Front. Neurosci. 7:108. doi: 10.3389/fnins.2013. 00108

De Nicola, A. F., Labombarda, F., Gonzalez Deniselle, M. C., Gonzalez, S. L., Garay, L., Meyer, M., et al. (2009). Progesterone neuroprotection in traumatic CNS injury and motoneuron degeneration. Front. Neuroendocrinol. 30, 173-187. doi: 10.1016/j.yfrne.2009.03.001

Desarnaud, F., Bidichandani, S., Patel, P. I., Baulieu, E. E., and Schumacher, M. (2000). Glucocorticosteroids stimulate the activity of the promoters of peripheral myelin protein-22 and protein zero genes in schwann cells. Brain Res. 865, 12-16. doi: 10.1016/s0006-8993(00)02130-2

Desarnaud, F., Do Thi, A. N., Brown, A. M., Lemke, G., Suter, U., Baulieu, E. E., et al. (1998). Progesterone stimulates the activity of the promoters of peripheral myelin protein-22 and protein zero genes in schwann cells. J. Neurochem. 71, 1765-1768. doi: 10.1046/j.1471-4159.1998.71041765.x

Dong, F., Xie, W., Strong, J. A., and Zhang, J. M. (2012). Mineralocorticoid receptor blocker eplerenone reduces pain behaviors in vivo and decreases excitability in small-diameter sensory neurons from local inflamed dorsal root ganglia in vitro. Anesthesiology 117, 1102-1112. doi: 10.1097/aln.0b013e3182 700383

Du, X., Hao, H., Yang, Y., Huang, S., Wang, C., Gigout, S., et al. (2017). Local GABAergic signaling within sensory ganglia controls peripheral nociceptive transmission. J. Clin. Invest. 127, 1741-1756. doi: 10.1172/jci86812

Dun, S. L., Brailoiu, G. C., Gao, X., Brailoiu, E., Arterburn, J. B., Prossnitz, E. R., et al. (2009). Expression of estrogen receptor GPR30 in the rat spinal cord and in autonomic and sensory ganglia. J. Neurosci. Res. 87, 1610-1619. doi: $10.1002 /$ jnr. 21980

Evans, P. D., Reale, V., Merzon, R. M., and Villegas, J. (1991). N-methyl-Daspartate (n.d.) and non-NMDA type glutamate receptors are present on squid giant axon Schwann cells. J. Exp. Biol. 157, 593-600.

Evans, P. D., Reale, V., Merzon, R. M., and Villegas, J. (1992). N-methyl-Daspartate (n.d.) and non-NMDA (metabotropic) type glutamate receptors modulate the membrane potential of the Schwann cell of the squid giant nerve fibre. J. Exp. Biol. 173, 229-249.

Faroni, A., Castelnovo, L. F., Procacci, P., Caffino, L., Fumagalli, F., Melfi, S., et al. (2014). Deletion of GABA-B receptor in Schwann cells regulates remak bundles and small nociceptive C-fibers. Glia 62, 548-565. doi: 10.1002/glia.22625

Faroni, A., and Magnaghi, V. (2011). The neurosteroid allopregnanolone modulates specific functions in central and peripheral glial cells. Front. Endocrinol. 2:103. doi: 10.3389/fnins.2013.00103

Faroni, A., Melfi, S., Castelnovo, L. F., Bonalume, V., Colleoni, D., Magni, P., et al. (2019). GABA-B1 receptor-null schwann cells exhibit compromised in vitro myelination. Mol. Neurobiol. 56, 1461-1474. doi: 10.1007/s12035-0181158 - $\mathrm{x}$

Fex Svenningsen, A., and Kanje, M. (1999). Estrogen and progesterone stimulate Schwann cell proliferation in a sex- and age-dependent manner. J. Neurosci. Res. 57, 124-130. doi: 10.1002/(sici)1097-4547(19990701)57:1<124::aid-jnr13> 3.0.co;2-p 
Fontenas, L., and Kucenas, S. (2018). Motor exit point (MEP) glia: novel myelinating glia that bridge CNS and PNS myelin. Front. Cell Neurosci. 12:333. doi: 10.3389/fnins.2013.00333

Frye, C. A., Van Keuren, K. R., and Erskine, M. S. (1996). Behavioral effects of 3 alpha-androstanediol. I: modulation of sexual receptivity and promotion of GABA-stimulated chloride flux. Behav. Brain Res. 79, 109-118. doi: 10.1016/ 0166-4328(96)00004-6

Gennari, C. G., Cilurzo, F., Mitro, N., Caruso, D., Minghetti, P., and Magnaghi, V. (2018). In vitro and in vivo evaluation of silk fibroin functionalized with GABA and allopregnanolone for Schwann cell and neuron survival. Regen. Med. 13, 141-157. doi: 10.2217/rme-2017-0102

Giatti, S., Garcia-Segura, L. M., and Melcangi, R. C. (2015). New steps forward in the neuroactive steroid field. J. Steroid Biochem. Mol. Biol. 153, 127-134. doi: 10.1016/j.jsbmb.2015.03.002

Giatti, S., Pesaresi, M., Cavaletti, G., Bianchi, R., Carozzi, V., Lombardi, R., et al. (2009). Neuroprotective effects of a ligand of translocator protein-18 kDa (Ro54864 ) in experimental diabetic neuropathy. Neuroscience 164, 520-529. doi: 10.1016/j.neuroscience.2009.08.005

Grossfeld, R. M., Klinge, M. A., Lieberman, E. M., and Stewart, L. C. (1988). Axonglia transfer of a protein and a carbohydrate. Glia 1, 292-300. doi: 10.1002/glia. 440010409

Groyer, G., Eychenne, B., Girard, C., Rajkowski, K., Schumacher, M., and Cadepond, F. (2006). Expression and functional state of the corticosteroid receptors and 11 beta-hydroxysteroid dehydrogenase type 2 in schwann cells. Endocrinology 147, 4339-4350. doi: 10.1210/en.2005-1625

Gu, Y., Wu, Y., Su, W., Xing, L., Shen, Y., He, X., et al. (2018). 17beta-estradiol enhances schwann cell differentiation via the ERbeta-ERK1/2 signaling pathway and promotes remyelination in injured sciatic nerves. Front. Pharmacol. 9:1026. doi: $10.3389 /$ fnins.2013.001026

Gudemez, E., Ozer, K., Cunningham, B., Siemionow, K., Browne, E., and Siemionow, M. (2002). Dehydroepiandrosterone as an enhancer of functional recovery following crush injury to rat sciatic nerve. Microsurgery 22, 234-241. doi: 10.1002/micr.10039

Guennoun, R., Benmessahel, Y., Delespierre, B., Gouezou, M., Rajkowski, K. M., Baulieu, E. E., et al. (2001). Progesterone stimulates Krox-20 gene expression in schwann cells. Brain Res. Mol. Brain Res. 90, 75-82. doi: 10.1016/s0169328x(01)00094-8

Handa, R. J., Pak, T. R., Kudwa, A. E., Lund, T. D., and Hinds, L. (2008), An alternate pathway for androgen regulation of brain function: activation of estrogen receptor beta by the metabolite of dihydrotestosterone, 5alphaandrostane-3beta,17beta-diol. Horm. Behav. 53, 741-752. doi: 10.1016/j.yhbeh. 2007.09.012

Hayashi, T., Maurice, T., and Su, T. P. (2000). Ca(2+) signaling via sigma(1)-receptors: novel regulatory mechanism affecting intracellular $\mathrm{Ca}(2+)$ concentration. J. Pharmacol. Exp. Ther. 293, 788-798.

Hodge, C. W., Raber, J., Mcmahon, T., Walter, H., Sanchez-Perez, A. M., Olive, M. F., et al. (2002). Decreased anxiety-like behavior, reduced stress hormones, and neurosteroid supersensitivity in mice lacking protein kinase cepsilon. J. Clin. Invest. 110, 1003-1010. doi: 10.1172/jci200215903

Hosie, A. M., Clarke, L., Da Silva, H., and Smart, T. G. (2009). Conserved site for neurosteroid modulation of GABA A receptors. Neuropharmacology 56, 149-154. doi: 10.1016/j.neuropharm.2008.07.050

Hosie, A. M., Wilkins, M. E., Da Silva, H. M., and Smart, T. G. (2006). Endogenous neurosteroids regulate GABAA receptors through two discrete transmembrane sites. Nature 444, 486-489. doi: 10.1038/nature05324

Islamov, R. R., Hendricks, W. A., Jones, R. J., Lyall, G. J., Spanier, N. S., and Murashov, A. K. (2002). 17Beta-estradiol stimulates regeneration of sciatic nerve in female mice. Brain Res. 943, 283-286. doi: 10.1016/s0006-8993(02) 02827-5

Jakobsson, T., Treuter, E., Gustafsson, J. A., and Steffensen, K. R. (2012). Liver X receptor biology and pharmacology: new pathways, challenges and opportunities. Trends Pharmacol. Sci. 33, 394-404. doi: 10.1016/j.tips.2012.03. 013

Jordan, C. L., Price, R. H. Jr., and Handa, R. J. (2002). Androgen receptor messenger RNA and protein in adult rat sciatic nerve: implications for site of androgen action. J. Neurosci. Res. 69, 509-518. doi: 10.1002/jnr.10324

Jung-Testas, I., Schumacher, M., Bugnard, H., and Baulieu, E. E. (1993). Stimulation of rat schwann cell proliferation by estradiol: synergism between the estrogen and cAMP. Brain Res. Dev. Brain Res. 72, 282-290. doi: 10.1016/ 0165-3806(93)90194-f

Jung-Testas, I., Schumacher, M., Robel, P., and Baulieu, E. E. (1996). Demonstration of progesterone receptors in rat schwann cells. J. Steroid Biochem. Mol. Biol. 58, 77-82. doi: 10.1016/0960-0760(96)00009-x

Koenig, H. L., Schumacher, M., Ferzaz, B., Thi, A. N., Ressouches, A., Guennoun, R., et al. (1995). Progesterone synthesis and myelin formation by schwann cells. Science 268, 1500-1503. doi: 10.1126/science.7770777

Kujawa, K. A., Jacob, J. M., and Jones, K. J. (1993). Testosterone regulation of the regenerative properties of injured rat sciatic motor neurons. J. Neurosci. Res. 35, 268-273. doi: 10.1002/jnr.490350306

Lambert, J. J., Belelli, D., Hill-Venning, C., Callachan, H., and Peters, J. A. (1996). Neurosteroid modulation of native and recombinant GABAA receptors. Cell Mol. Neurobiol. 16, 155-174. doi: 10.1007/bf02088174

Lambert, J. J., Belelli, D., Peden, D. R., Vardy, A. W., and Peters, J. A. (2003). Neurosteroid modulation of GABAA receptors. Prog. Neurobiol. 71, 67-80.

Lambert, J. J., Cooper, M. A., Simmons, R. D., Weir, C. J., and Belelli, D. (2009). Neurosteroids: endogenous allosteric modulators of GABA(A) receptors. Psychoneuroendocrinology 34(Suppl. 1), S48-S58.

Leonelli, E., Bianchi, R., Cavaletti, G., Caruso, D., Crippa, D., Garcia-Segura, L. M., et al. (2007). Progesterone and its derivatives are neuroprotective agents in experimental diabetic neuropathy: a multimodal analysis. Neuroscience 144, 1293-1304. doi: 10.1016/j.neuroscience.2006.11.014

Lerch, J. K., Alexander, J. K., Madalena, K. M., Motti, D., Quach, T., Dhamija, A., et al. (2017). Stress increases peripheral axon growth and regeneration through glucocorticoid receptor-dependent transcriptional programs. eNeuro 4:ENEURO.0246-17.2017.

Levin, E. R. (2011). Minireview: extranuclear steroid receptors: roles in modulation of cell functions. Mol. Endocrinol. 25, 377-384. doi: 10.1210/me.2010-0284

Li, H., and Papadopoulos, V. (1998). Peripheral-type benzodiazepine receptor function in cholesterol transport. Identification of a putative cholesterol recognition/interaction amino acid sequence and consensus pattern. Endocrinology 139, 4991-4997. doi: 10.1210/endo.139.12.6390

Lopez-Verrilli, M. A., and Court, F. A. (2012). Transfer of vesicles from schwann cells to axons: a novel mechanism of communication in the peripheral nervous system. Front. Physiol. 3:205. doi: 10.3389/fnins.2013.00205

Luo, H., Liu, J., Kang, D., and Cui, S. (2008). Ontogeny of estrogen receptor alpha, estrogen receptor beta and androgen receptor, and their co-localization with Islet-1 in the dorsal root ganglia of sheep fetuses during gestation. Histochem. Cell Biol. 129, 525-533. doi: 10.1007/s00418-008-0380-4

Magnaghi, V. (2007). GABA and neuroactive steroid interactions in glia: new roles for old players? Curr. Neuropharmacol. 5, 47-64. doi: 10.2174/ 157015907780077132

Magnaghi, V., Ballabio, M., Cavarretta, I. T., Froestl, W., Lambert, J. J., Zucchi, I., et al. (2004). GABAB receptors in schwann cells influence proliferation and myelin protein expression. Eur. J. Neurosci. 19, 2641-2649. doi: 10.1111/j.0953816x.2004.03368.x

Magnaghi, V., Ballabio, M., Consoli, A., Lambert, J. J., Roglio, I., and Melcangi, R. C. (2006a). GABA receptor-mediated effects in the peripheral nervous system: a cross-interaction with neuroactive steroids. J. Mol. Neurosci. 28, 89-102. doi: 10.1385/jmn:28:1:89

Magnaghi, V., Veiga, S., Ballabio, M., Gonzalez, L. C., Garcia-Segura, L. M., and Melcangi, R. C. (2006b). Sex-dimorphic effects of progesterone and its reduced metabolites on gene expression of myelin proteins by rat schwann cells. J. Peripher. Nerv. Syst. 11, 111-118. doi: 10.1111/j.1085-9489.2006.00075.x

Magnaghi, V., Ballabio, M., Roglio, I., and Melcangi, R. C. (2007). Progesterone derivatives increase expression of Krox-20 and Sox-10 in rat Schwann cells. J. Mol. Neurosci. 31, 149-157.

Magnaghi, V., Castelnovo, L. F., Faroni, A., Cavalli, E., Caffino, L., Colciago, A., et al. (2014). Nerve regenerative effects of GABA-B ligands in a model of neuropathic pain. Biomed. Res. Int. 2014:368678.

Magnaghi, V., Cavarretta, I., Galbiati, M., Martini, L., and Melcangi, R. C. (2001). Neuroactive steroids and peripheral myelin proteins. Brain Res. Brain Res. Rev. 37, 360-371. doi: 10.1016/s0165-0173(01)00140-0

Magnaghi, V., Cavarretta, I., Zucchi, I., Susani, L., Rupprecht, R., Hermann, B., et al. (1999). Po gene expression is modulated by androgens in the sciatic nerve of adult male rats. Brain Res. Mol. Brain Res. 70, 36-44. doi: 10.1016/s0169328x(99)00124-2 
Magnaghi, V., Parducz, A., Frasca, A., Ballabio, M., Procacci, P., Racagni, G., et al. (2010). GABA synthesis in schwann cells is induced by the neuroactive steroid allopregnanolone. J. Neurochem. 112, 980-990. doi: 10.1111/j.1471-4159.2009. 06512.x

Malet, M., and Brumovsky, P. R. (2015). VGLUTs and glutamate synthesis-focus on DRG neurons and pain. Biomolecules 5, 3416-3437. doi: 10.3390/biom5043416

Mantelas, A., Stamatakis, A., Kazanis, I., Philippidis, H., and Stylianopoulou, F. (2003). Control of neuronal nitric oxide synthase and brain-derived neurotrophic factor levels by GABA-A receptors in the developing rat cortex. Brain Res. Dev. Brain Res. 145, 185-195. doi: 10.1016/j.devbrainres.2003.08.001

Maurice, T., Phan, V. L., Urani, A., Kamei, H., Noda, Y., and Nabeshima, T. (1999). Neuroactive neurosteroids as endogenous effectors for the sigmal (sigma1) receptor: pharmacological evidence and therapeutic opportunities. Jpn. J. Pharmacol. 81, 125-155. doi: 10.1254/jjp.81.125

Meffre, D., Labombarda, F., Delespierre, B., Chastre, A., De Nicola, A. F., Stein, D. G., et al. (2013). Distribution of membrane progesterone receptor alpha in the male mouse and rat brain and its regulation after traumatic brain injury. Neuroscience 231, 111-124. doi: 10.1016/j.neuroscience.2012.11.039

Melcangi, R. C., Celotti, F., Ballabio, M., Poletti, A., and Martini, L. (1990). Testosterone metabolism in peripheral nerves: presence of the 5 alphareductase-3 alpha-hydroxysteroid-dehydrogenase enzymatic system in the sciatic nerve of adult and aged rats. J. Steroid Biochem. 35, 145-148. doi: 10. 1016/0022-4731(90)90159-p

Melcangi, R. C., Celotti, F., Castano, P., and Martini, L. (1992). Is the 5 alphareductase- 3 alpha-hydroxysteroid dehydrogenase complex associated with the myelin in the peripheral nervous system of young and old male rats? Endocr. Regul. 26, 119-125.

Melcangi, R. C., Giatti, S., and Garcia-Segura, L. M. (2016). Levels and actions of neuroactive steroids in the nervous system under physiological and pathological conditions: sex-specific features. Neurosci. Biobehav. Rev. 67, 25-40. doi: 10. 1016/j.neubiorev.2015.09.023

Melcangi, R. C., Leonelli, E., Magnaghi, V., Gherardi, G., Nobbio, L., and Schenone, A. (2003). Mifepristone (RU 38486) influences expression of glycoprotein Po and morphological parameters at the level of rat sciatic nerve: in vivo observations. Exp. Neurol. 184, 930-938. doi: 10.1016/s0014-4886(03)00338-8

Melcangi, R. C., Magnaghi, V., Cavarretta, I., Martini, L., and Piva, F. (1998). Ageinduced decrease of glycoprotein Po and myelin basic protein gene expression in the rat sciatic nerve. Repair by steroid derivatives. Neuroscience 85, 569-578. doi: 10.1016/s0306-4522(97)00628-3

Melcangi, R. C., Magnaghi, V., Cavarretta, I., Zucchi, I., Bovolin, P., D’urso, D., et al. (1999a). Progesterone derivatives are able to influence peripheral myelin protein 22 and P0 gene expression: possible mechanisms of action. J. Neurosci. Res. 56, 349-357. doi: 10.1002/(sici)1097-4547(19990515)56:4<349::aid-jnr3> 3.0.co; $2-\mathrm{h}$

Melcangi, R. C., Magnaghi, V., and Martini, L. (1999b). Steroid metabolism and effects in central and peripheral glial cells. J. Neurobiol. 40, 471-483. doi: 10. 1002/(sici)1097-4695(19990915)40:4<471::aid-neu5>3.0.co;2-p

Melcangi, R. C., Magnaghi, V., Galbiati, M., Ghelarducci, B., Sebastiani, L., and Martini, L. (2000a). The action of steroid hormones on peripheral myelin proteins: a possible new tool for the rebuilding of myelin? J. Neurocytol. 29, 327-339.

Melcangi, R. C., Magnaghi, V., and Martini, L. (2000b). Aging in peripheral nerves: regulation of myelin protein genes by steroid hormones. Prog. Neurobiol. 60, 291-308. doi: 10.1016/s0301-0082(99)00028-3

Melcangi, R. C., Magnaghi, V., Galbiati, M., and Martini, L. (2001). Formation and effects of neuroactive steroids in the central and peripheral nervous system. Int. Rev. Neurobiol. 46, 145-176. doi: 10.1016/s0074-7742(01)46062-4

Melfi, S., Montt Guevara, M. M., Bonalume, V., Ruscica, M., Colciago, A., Simoncini, T., et al. (2017). Src and phospho-FAK kinases are activated by allopregnanolone promoting Schwann cell motility, morphology and myelination. J. Neurochem. 141, 165-178. doi: 10.1111/jnc.13951

Mercier, G., Turque, N., and Schumacher, M. (2001). Early activation of transcription factor expression in schwann cells by progesterone. Brain Res. Mol. Brain Res. 97, 137-148. doi: 10.1016/s0169-328x(01)00311-4

Mihalek, R. M., Banerjee, P. K., Korpi, E. R., Quinlan, J. J., Firestone, L. L., Mi, Z. P., et al. (1999). Attenuated sensitivity to neuroactive steroids in gammaaminobutyrate type A receptor delta subunit knockout mice. Proc. Natl. Acad. Sci. U.S.A. 96, 12905-12910. doi: 10.1073/pnas.96.22.12905
Miller, K. E., Richards, B. A., and Kriebel, R. M. (2002). Glutamine-, glutamine synthetase-, glutamate dehydrogenase- and pyruvate carboxylaseimmunoreactivities in the rat dorsal root ganglion and peripheral nerve. Brain Res. 945, 202-211. doi: 10.1016/s0006-8993(02)02802-0

Mitro, N., Cermenati, G., Brioschi, E., Abbiati, F., Audano, M., Giatti, S., et al. (2014). Neuroactive steroid treatment modulates myelin lipid profile in diabetic peripheral neuropathy. J. Steroid Biochem. Mol. Biol. 143, 115-121. doi: 10.1016/ j.jsbmb.2014.02.015

Monnet, F. P., and Maurice, T. (2006). The sigmal protein as a target for the non-genomic effects of neuro(active)steroids: molecular, physiological, and behavioral aspects. J. Pharmacol. Sci. 100, 93-118. doi: 10.1254/jphs.cr00 50032

Morris, M. E., Di Costanzo, G. A., Fox, S., and Werman, R. (1983). Depolarizing action of GABA (gamma-aminobutyric acid) on myelinated fibers of peripheral nerves. Brain Res. 278, 117-126. doi: 10.1016/0006-8993(83)90230-5

Moss, S. J., and Smart, T. G. (1996). Modulation of amino acid-gated ion channels by protein phosphorylation. Int. Rev. Neurobiol. 39, 1-52. doi: 10.1016/s00747742(08)60662-5

Neuberger, T. J., Kalimi, O., Regelson, W., Kalimi, M., and De Vries, G. H. (1994). Glucocorticoids enhance the potency of schwann cell mitogens. J. Neurosci. Res. 38, 300-313. doi: 10.1002/jnr.490380308

Olsen, R. W., Snowhill, E. W., and Wamsley, J. K. (1984). Autoradiographic localization of low affinity GABA receptors with [3H]bicuculline methochloride. Eur. J. Pharmacol. 99, 247-248. doi: 10.1016/0014-2999(84) 90249-8

Pabba, M., and Sibille, E. (2015). Sigma-1 and N-Methyl-d-Aspartate receptors: a partnership with beneficial outcomes. Mol. Neuropsychiat. 1, 47-51. doi: 10. $1159 / 000376549$

Park-Chung, M., Malayev, A., Purdy, R. H., Gibbs, T. T., and Farb, D. H. (1999). Sulfated and unsulfated steroids modulate gamma-aminobutyric acidA receptor function through distinct sites. Brain Res. 830, 72-87. doi: 10.1016/ s0006-8993(99)01381-5

Patte-Mensah, C., Meyer, L., Taleb, O., and Mensah-Nyagan, A. G. (2014). Potential role of allopregnanolone for a safe and effective therapy of neuropathic pain. Prog. Neurobiol. 113, 70-78. doi: 10.1016/j.pneurobio.2013.07.004

Peluso, J. J., Romak, J., and Liu, X. (2008). Progesterone receptor membrane component-1 (PGRMC1) is the mediator of progesterone's antiapoptotic action in spontaneously immortalized granulosa cells as revealed by PGRMC1 small interfering ribonucleic acid treatment and functional analysis of PGRMC1 mutations. Endocrinology 149, 534-543. doi: 10.1210/en. 2007-1050

Perego, C., Cairano, E. S., Ballabio, M., and Magnaghi, V. (2011). Neurosteroid allopregnanolone regulates EAAC1-mediated glutamate uptake and triggers actin changes in schwann cells. J. Cell Physiol. 227, 1740-1751.

Perego, C., Di Cairano, E. S., Ballabio, M., and Magnaghi, V. (2012). Neurosteroid allopregnanolone regulates EAAC1-mediated glutamate uptake and triggers actin changes in schwann cells. J. Cell. Physiol. 227, 1740-1751. doi: 10.1002/ jcp. 22898

Pesaresi, M., Giatti, S., Cavaletti, G., Abbiati, F., Calabrese, D., Bianchi, R., et al. (2011a). Sex differences in the manifestation of peripheral diabetic neuropathy in gonadectomized rats: a correlation with the levels of neuroactive steroids in the sciatic nerve. Exp. Neurol. 228, 215-221. doi: 10.1016/j.expneurol.2011.01. 005

Pesaresi, M., Giatti, S., Cavaletti, G., Abbiati, F., Calabrese, D., Lombardi, R., et al. (2011b). Sex-dimorphic effects of dehydroepiandrosterone in diabetic neuropathy. Neuroscience 199, 401-409. doi: 10.1016/j.neuroscience.2011.09. 013

Pesaresi, M., Maschi, O., Giatti, S., Garcia-Segura, L. M., Caruso, D., and Melcangi, R. C. (2010). Sex differences in neuroactive steroid levels in the nervous system of diabetic and non-diabetic rats. Horm. Behav. 57, 46-55. doi: 10.1016/j.yhbeh. 2009.04.008

Prough, R. A., Clark, B. J., and Klinge, C. M. (2016). Novel mechanisms for DHEA action. J. Mol. Endocrinol. 56, R139-R155.

Puia, G., Ravazzini, F., Castelnovo, L. F., and Magnaghi, V. (2015). PKCepsilon and allopregnanolone: functional cross-talk at the GABAA receptor level. Front. Cell. Neurosci. 9:83. doi: 10.3389/fnins.2013.0083

Reddy, D. S., and Rogawski, M. A. (2002). Stress-induced deoxycorticosteronederived neurosteroids modulate $\mathrm{GABA}(\mathrm{A})$ receptor function and seizure 
susceptibility. J. Neurosci. 22, 3795-3805. doi: 10.1523/jneurosci.22-09-03795. 2002

Robert, F., Guennoun, R., Desarnaud, F., Do-Thi, A., Benmessahel, Y., Baulieu, E. E., et al. (2001). Synthesis of progesterone in schwann cells: regulation by sensory neurons. Eur. J. Neurosci. 13, 916-924. doi: 10.1046/j.0953-816x.2001. 01463.x

Roglio, I., Bianchi, R., Giatti, S., Cavaletti, G., Caruso, D., Scurati, S., et al. (2007). Testosterone derivatives are neuroprotective agents in experimental diabetic neuropathy. Cell. Mol. Life Sci. 64, 1158-1168. doi: 10.1007/s00018-007-7002-5

Roglio, I., Bianchi, R., Gotti, S., Scurati, S., Giatti, S., Pesaresi, M., et al. (2008). Neuroprotective effects of dihydroprogesterone and progesterone in an experimental model of nerve crush injury. Neuroscience 155, 673-685. doi: 10.1016/j.neuroscience.2008.06.034

Rupprecht, R., Di Michele, F., Hermann, B., Strohle, A., Lancel, M., Romeo, E., et al. (2001). Neuroactive steroids: molecular mechanisms of action and implications for neuropsychopharmacology. Brain Res. Brain Res. Rev. 37, 59-67. doi: 10. 1016/s0165-0173(01)00123-0

Schaeffer, V., Meyer, L., Patte-Mensah, C., and Mensah-Nyagan, A. G. (2010). Progress in dorsal root ganglion neurosteroidogenic activity: basic evidence and pathophysiological correlation. Prog. Neurobiol. 92, 33-41. doi: 10.1016/ j.pneurobio.2010.04.009

Schumacher, M., Guennoun, R., Mercier, G., Desarnaud, F., Lacor, P., Benavides, J., et al. (2001). Progesterone synthesis and myelin formation in peripheral nerves. Brain Res. Brain Res. Rev. 37, 343-359. doi: 10.1016/s0165-0173(01) 00139-4

Sedlacek, M., Korinek, M., Petrovic, M., Cais, O., Adamusova, E., Chodounska, H., et al. (2008). Neurosteroid modulation of ionotropic glutamate receptors and excitatory synaptic transmission. Physiol. Res. 57(Suppl. 3), S49-S57.

Shaqura, M., Li, X., Al-Khrasani, M., Shakibaei, M., Tafelski, S., Furst, S., et al. (2016). Membrane-bound glucocorticoid receptors on distinct nociceptive neurons as potential targets for pain control through rapid non-genomic effects. Neuropharmacology 111, 1-13. doi: 10.1016/j.neuropharm.2016. 08.019

Shu, H. J., Eisenman, L. N., Jinadasa, D., Covey, D. F., Zorumski, C. F., and Mennerick, S. (2004). Slow actions of neuroactive steroids at GABAA receptors. J. Neurosci. 24, 6667-6675. doi: 10.1523/jneurosci.1399-04.2004

Siriphorn, A., Chompoopong, S., and Floyd, C. L. (2010). 17beta-estradiol protects Schwann cells against $\mathrm{H} 2 \mathrm{O} 2$-induced cytotoxicity and increases transplanted Schwann cell survival in a cervical hemicontusion spinal cord injury model. J. Neurochem. 115, 864-872. doi: 10.1111/j.1471-4159.2010.06770.x

Slater, E. P., Hesse, H., and Beato, M. (1994). Regulation of transcription by steroid hormones. Ann. N. Y. Acad. Sci. 733, 103-112.
Thomas, P., and Pang, Y. (2012). Membrane progesterone receptors: evidence for neuroprotective, neurosteroid signaling and neuroendocrine functions in neuronal cells. Neuroendocrinology 96, 162-171. doi: 10.1159/000339822

Thomas, P., Pang, Y., Filardo, E. J., and Dong, J. (2005). Identity of an estrogen membrane receptor coupled to a $\mathrm{G}$ protein in human breast cancer cells. Endocrinology 146, 624-632. doi: 10.1210/en.2004-1064

Veiga, S., Leonelli, E., Beelke, M., Garcia-Segura, L. M., and Melcangi, R. C. (2006). Neuroactive steroids prevent peripheral myelin alterations induced by diabetes. Neurosci. Lett. 402, 150-153. doi: 10.1016/j.neulet.2006.03.058

Vergnano, A. M., Schlichter, R., and Poisbeau, P. (2007). PKC activation sets an upper limit to the functional plasticity of GABAergic transmission induced by endogenous neurosteroids. Eur. J. Neurosci. 26, 1173-1182. doi: 10.1111/j.14609568.2007.05746.x

Wang, M., He, Y., Eisenman, L. N., Fields, C., Zeng, C. M., Mathews, J., et al. (2002). 3beta -hydroxypregnane steroids are pregnenolone sulfate-like GABA(A) receptor antagonists. J. Neurosci. 22, 3366-3375. doi: 10.1523/ jneurosci.22-09-03366.2002

Whiting, P. J., Mcallister, G., Vassilatis, D., Bonnert, T. P., Heavens, R. P., Smith, D. W., et al. (1997). Neuronally restricted RNA splicing regulates the expression of a novel GABAA receptor subunit conferring atypical functional properties [corrected; erratum to be published]. J. Neurosci. 17, 5027-5037. doi: 10.1523/ jneurosci.17-13-05027.1997

Whiting, P. J., Mckernan, R. M., and Wafford, K. A. (1995). Structure and pharmacology of vertebrate GABAA receptor subtypes. Int. Rev. Neurobiol. 38, 95-138. doi: 10.1016/s0074-7742(08)60525-5

Wu, F. S., Gibbs, T. T., and Farb, D. H. (1991). Pregnenolone sulfate: a positive allosteric modulator at the N-methyl-D-aspartate receptor. Mol. Pharmacol. 40, 333-336.

Zhang, X. L., Lee, K. Y., Priest, B. T., Belfer, I., and Gold, M. S. (2015). Inflammatory mediator-induced modulation of GABAA currents in human sensory neurons. Neuroscience 310, 401-409. doi: 10.1016/j.neuroscience.2015.09.048

Conflict of Interest: The authors declare that the research was conducted in the absence of any commercial or financial relationships that could be construed as a potential conflict of interest.

Copyright (c) 2020 Colciago, Bonalume, Melfi and Magnaghi. This is an open-access article distributed under the terms of the Creative Commons Attribution License (CC BY). The use, distribution or reproduction in other forums is permitted, provided the original author(s) and the copyright owner(s) are credited and that the original publication in this journal is cited, in accordance with accepted academic practice. No use, distribution or reproduction is permitted which does not comply with these terms. 